\title{
Pilgrims and Pilgrimages in the Critique of Enlightenment - A Case Study
}

\author{
Wolfgang Wuest \\ Department of History, Friedrich-Alexander-University Erlangen-Nuremberg, Erlangen, Germany \\ Email address: \\ wolfgang.wuest@fau.de \\ To cite this article: \\ Wolfgang Wuest. Pilgrims and Pilgrimages in the Critique of Enlightenment - A Case Study. History Research. \\ Vol. 7, No. 1, 2019, pp. 17-26. doi: 10.11648/j.history.20190701.13
}

Received: March 17, 2019; Accepted: August 12, 2019; Published: September 5, 2019

\begin{abstract}
The exploration of pilgrimage, of pilgrims' distances, destinations and christian worship have for a long time been studied by historians, theologians and ethnologists. Modern authors and recent books say, pilgrimage is a field for permanent investigation. Illustrated calendars on pilgrimage, printed in the catholic "Weltbild" Publishing House, promise almost everything for good to motivate believers to go on pilgrimage. Research in pilgrimage concentrated on early periods and high times of worshipping and Christianity. The criticism of the $18^{\text {th }}$ and $19^{\text {th }}$ century was only sparely reflected. In contrast to the mainstream we concentrate on this critical period. The reason why pilgrims have been criticized since that time has to do with the contemporary legislation, the benevolent "Policey". Courts accused people of being lazy, work-shy and inward-looking. Quarrels turned around beer drinkers and alehouses next to churches and cemeteries. Last but not least employers and entrepreneurs said, there is a harmful overflow of church festivals und pilgrim-worshippings. They will ruin our economy!
\end{abstract}

Keywords: Pilgrimage, Worshipping, Enlightenment, Religion, Christianity, Church Criticism, Superstition

\section{Introduction}

The study of pilgrimages, individual places of pilgrimage [1] and their cults as well as pilgrim paths [2] has long been an established field of church and regional history as well as folkloristic research. [3] New publications emphasize an almost timeless research concern. Pilgrimage calendars also promise euphorically to this day: "Pilgrimage churches are fascinating places of contemplation and hold a long Christian tradition. Experience sublime buildings in which heaven and earth touch, from the Basilica of the Nativity of the Virgin Mary in Styria to Mont Saint-Michel in Brittany. An impressive series of pictures that invites everyone on a pilgrimage". [4] The temporal research focus naturally lay in the time of origin and heyday of individual pilgrimage centres, less in the late period than in the biting criticism [5] and mockery of reliquary and miracle-despising enlighteners. Here we want to set our focus in order to place the pilgrimage events in the general context of the development of "Policey"-norms from the 17 th to the 19 th century and to ask about the special piety and church criticism in the Enlightenment of pilgrimage. Conservative church circles saw the reference to church orders, processions, cloisters and pilgrimages as an anchor of hope against the fundamental criticism of the rite of faith, of the origin of piety and of the saints and cult of relics, which were hereticized as superstitions but indispensable for flourishing pilgrimages. In 1787, for example, the Augsburg cathedral preacher Georg Zeiler refused to ring in the end of the prayer and cloisters to the "Holy Mountain" in Andechs monastery from the pulpit to the cathedral vicariate. He rather referred to the cleansing power of the church norms: "all das gefährliche, unordentliche, anstössige, versäumende und zerstreuende,

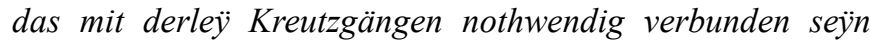
muß, wird verhindert und unmöglich gemacht, wenn die gläubigen dem Inhalte dieser verordnung nachkom [m]en". [6] And the cathedral preacher sighed in view of the widespread criticism of pilgrimages: "I am supposed to convince the people of what I cannot convince myself of". In his decision of faith he appealed beside episcopal decrees and papal cops to the model of the "most famous saints, especially of Saint Ulrich, bishop and patron saint of our diocese, who was known as a great esteemer of pilgrimages in remote places". [6] Pilgrimage enthusiasts such as Georg Zeiler, however, were increasingly in need of explanations during the Enlightenment. Fewer and fewer Christians still 
believed what, for example, Mary Magdalene, venerated at the Burgundian place of pilgrimage Vézelay [7], had long believed: "Out of love for this saint the Lord forgives the sinners their transgressions, he gives sight to the blind, he loosens the tongue of the mute; lame people are raised up, possessed people are freed from the demon, many others receive here unspeakable favours". [8]

In particular, it was the theological and social controversies about exorcism as well as about the belief in hell and the devil, which in the Enlightenment soon led to a fundamental criticism against all traditional church and piety rites. The ethnologist Daniel Drascek from Regensburg examined in this context the case of the miracle healer and exorcist Johann Joseph Gaßner (1727-1779), who caused a sensation throughout southern Germany. He had first performed spectacular "healings" in the name of Christ in the prince provostry of Ellwangen and later in the diocese and the imperial city of Regensburg. Even the conservative prince provost of Ellwangen and prince-bishop of Augsburg, Clemens Wenzeslaus of Saxony (1768-1802/ 1812) [9], had the case examined by a high-ranking commission of experts. As a result, no supernatural forces could be proven. So everything remained speculation and charlatanry, but the follow-up controversies around Gaßner led, for example, in the Regensburg diocese from the prohibition of still popular pilgrimages lasting several days to the abolition of the Passion Plays to the ban on scripts for parishes in the Christmas season. [10]

\section{Policey and Pilgrimage}

\subsection{Beggars, the Poor and Diseases}

In the early modern era, pilgrims were the focus of legislation on several occasions. One of the reasons was the fight against idleness, begging and the search for grace, which was averted from the world and responsibility. In social terms, the flows of pilgrims to nationally known places of pilgrimage in southern Germany were too staggered to allow praying believers, the sick, those seeking help and charlatans not to come into the focus of police research. At first, this particularly affected the group of pilgrims of alms and poverty, who always represented a challenge for the dioceses and church centres. In 1548 the Bamberger Hochstift therefore issued its own begging order, which also included domestic pilgrims. Anyone who violated it had to reckon with a temporary ban on the use of land and cities. "Auch sol niemant der sich ein walfart mit dem Almusen zuuerbringen anmast/dartzu petteln/ oder samlen/ er sey dan zuuor durch vnsern Ungelter/ mit seiner erlaubnus zugelassen/ auch dessen ein zeichen/von ime empfangen/ Welcher das vberfert/ dem sol die Sta ein Jar versaget sein." [11] Believers and travellers in early modern times confirmed this not uncommon connection of pilgrimage and begging. When the Benedictine monks Fr. Beda Plank and Fr. Thaddäus Derflinger from Kremsmünster in 1779 travelled through the Swabian imperial city of Kaufbeuren, where the grave of Maria Crescentia Höss (1682-1744) [12] - she was canonized in 2001 - was located in the monastery of the Franciscan nuns: "Uibrigens gibt es hier, wie in allen renommierten Wallfahrten, Bettler fast so viel als Opfertafeln, und man muß froh seyn, wenn man sein Quartier noch mit ganzen Schuhen erreichet." [13] There were therefore also conflicts of interest with the early modern world of work. When in the Lower Franconian pilgrimage place Hessenthal not far from Mespelbrunn, where already in 1993 one could look back on a 700 years old St. Marypilgrimage-tradition, a yarn cook at Whitsun was asked about her holiday sacrilege, she replied: "Why do I care about your Whit Monday and your pilgrimage! Pilgrimages may go if you know nothing better to do". [14]

The legislation of the territories around important places of pilgrimage, however, also worried about the spread of infectious diseases as so-called disease prevention, since pilgrims seeking help sometimes went on deathly ill pilgrimages to the places of grace. At the destination and on the way, the danger of spreading was great, the faithful concentrated around the churches and hostels. Votive boards [15] in pilgrimage churches report in pictures and text about the endless suffering of the people. In 1731, for example, Matthäus Fleck from Hainhofen and Johannes Funck from Biberbach made a pilgrimage to Maria Einsiedeln in Switzerland from the district of Augsburg because of his epilepsy and lung addiction respectively. And in 1747 Johann Hofbauer from Zusmarshausen made a vow that because of his painful cold fever, he wanted to "bey Wasser und Brodt bisher Steinbach [16] wallen." [17] These were pilgrimagerelated illnesses that were picked up in the early modern Policey. In addition to regulations on going to church, the work, craft, guild and trade situation [18], it also included preventive health care. This regionally not yet sufficiently medic Policey [19] culminated in the possibility for the out and rejection of sick persons with epidemic danger. [20]

\subsection{Beer Consumption and Beer Serving}

Elsewhere, it was about the lucrative serving of beer [21] in inns near churches on pilgrim and festival days, which once it had been monopolized by the ruling class - had to be protected and defended by decree as a by no means insignificant source of tax. Pilgrimage beers are still part of the product range of individual breweries today. Thus the Gässl brewery in Pfarrkirchen in the Rottal places a Gartlberger pilgrimage beer" [22] into the product range and in the Mary's place Gößweinstein near Bamberg one presents from the brewery Held in the neighbouring Oberailsfeld [23] tradition-rich "Gösswein-stein pilgrimage beer". [24] It is not surprising that tax disputes have repeatedly arisen in this regard. Thus there was also a conflict on the border between the Augsburger Hochstift and the Electorate of Bavaria regarding the serving of beer, despite a border treaty dating from 1785. In the Swabian-Bavarian border town Dietlried ("Dietelried") near Schwabsoien, where the pilgrimage came to an end in the secularization year 1803, there was a showdown in 1788 concerning pilgrimage beer. The Bavarian 
president of the regional government and vice-chancellor Count Morawitzky complained: "Abschriftlich anliegende zwey Producte geben in weiteren zu entnehmen, daß die Bräuschaft der inländischen Stadt Schongau schon von der in Anno 1785 mit dem Hochstifte Augsburg beschehenen GränzAusgleichung das Recht hatte, in dem Wallfahrts-Orte Dietlried, so vorhin unter das obige Landgericht Schongau gehörte, in den am Maria Himmelfahrts- und Ulrichs-Tage, abgehaltenen Märkten, braunes Bier auszuschenken: Gleiches hatten auch die gegenseitigen Wirthe mit ihrem Gerstenbier gethann, ohne daß ihnen dießseits der mindeste Einhalt geschah. Da der nämliche Bräuer von Schongau, den das Loos im letzte vergangenen Jahre dahin zuziehen dieses hergebrachte Recht auszuüben anfangen wollte, so kam sogleich der fronboth mit dem vom Pflegamte Oberdorf erhaltenen Befehle, daß kein Schongauischer Bräu bey Strafe sich mehr unterstehe, im ersagten Orte einiges Bier zu verschleißen." [25] Tavern and pilgrimage church formed a firm unit until the "long" 19th century. When in 1821 a thirsty long-distance traveller from Munich became aware of this fact, he stood in front of closed doors in the Allgäu parish and pilgrimage town of Obergermaringen: “...alles Rufen nach dem Wirtshaus, das rechts an der Straße steht, war vergebens und der bescheidene Wunsch, obwohl sehr laut ausgesprochen blieb unerfüllt. Eine schöne Kirche mit zwei Türmen wollten wir besehen, aber sie war uns, wie das Wirtshaus verschlossen und ich dachte an das alte Wallfahrts-Sprüchlein: 'Wer nicht betet, soll auch nicht trinken'." [26] The proximity of the brewmasters and the beer to the holy sites, despite the welcome income from the lack of money, also called the admonishing authorities to the scene early on. It was not only about drinking [27] and beer consumption, but also about the institution of the inn with all its tempting offers. In 1770 the prince-bishop Adam Friedrich von Seinsheim (Würzburg: 1755-1779), who reigned in Bamberg [28] and Würzburg at the same time, spoke: "Beharren Wir auf unsrer de [n] 18 Juny 1765 ergangene [n] Verordnung, Inhalts welcher an den Sonn- und unsers Heilands Festen, als den I Weihnachts- Neujahrs- $H$ [eiligen] $3 \mathrm{Ko}^{e}$ nigen- Christi Himmelfahrt- und Fronleichnams-Tag alles Tanzen und Musik halten in den Wirthsha usern unter namhafter Bestrafung ga nzlich verbothen bleibet; auf anderen Festen aber Nachmittag von 5 bis 10 Uhr im Sommer, und bis 9 Uhr im Winter gleichwohl verstattet ist. Auf gleiche Art auch ist in Zukunft nicht erlaubt, an bemeldten Sonn- und erstberu'hrten unsers Herrn Ta gen offentliche Lustbarkeiten, als Como dien, Bale und Schlittenfahrten anzustellen." [29]

\section{Reduced Number of Requests, Processions, Holidays and Pilgrimages}

\subsection{Processions}

Criticism of superfluous petitions, processions and, more specifically, pilgrimages and processions was voiced long before the Enlightenment. Even Catholic sovereigns complained of idleness, debauchery, drunkenness and empty litanies over church, village and police regulations. These shortcomings occurred in the context of pilgrimages, church consecrations, patron saint's feasts as well as vows and consecration anniversaries. In the Hochstift Würzburg the church order of 1693 regulated in a section to "Feyerta gen, Kirchweihungen, Patrociniis und Wallfahrten" accordingly. The spiritual council and the prince-bishops' government interrogated, "welcher gestalt an vielen Orten, die also genannten von den Gemeinden, ohne unser und unsers nachgesetzten geistlichen Raths Vorwissen und Verwilligung angestellten Hagelfeyer oder Gelu bdfeste mit Enthaltung knechtlicher Arbeit ja hrlich begangen werden, und aber dieses den heilsamen Kirchensatzungen, Kraft deren die Einsetzung der heiligen Festta ${ }^{e}$ ge allein durch bischo flichen Gewalt geschehen soll, gerad zuwider, der allma chtige Gottauch damit wenig geehrt, sondern vielmehr durch den verderblichen, und auch den gemeinen Leuten an ihrer Nahrung schaedlichen Mußßiggang, und andere aus denenselben entstehende Uebertrettung go ${ }^{e}$ ttlichen Gesa ${ }^{e}$ tzes erzo ${ }^{e}$ rnet wird, auch ohne das zu der dadurch verhoffenden Abwendung der Pest und anderer ansteckenden Krankheiten, des Ungewitters, und Erhaltung der lieben Fru chten auf dem Feld die gewo hnlichen uralten von christlicher katholischer Kirche eingesetzten Wallfahrten an S. Marci Tag, und in der Kreuzwoche, wenn sie nur mit aller Gottesforcht, Andacht und guter Ordnung verrichtet werden, vielmehr als solche aus eigenem Willen unbesonnenerweis von dem gemeinen Volk gelobten Feyerta ${ }^{e}$ ersprießlich seyn werden: als ist unser gna digst befehlender Will und Verordnung, daß forthin, außer einem und den in angeregter unserer KirchenAgend verzeichneten Festen, alle andern (die Kirchweihen und jedes Orts Patrocinien allein ausgenommen) aufgehoben seyn sollen." [30]

\subsection{Church-holidays}

The dense network of pilgrimage sites in the south and west of the Germania Sacra and the popularity of even smaller pilgrimage churches contributed to the territorial restrictions of the multitude of holidays and sacrificial days at the latest in the Enlightenment. The pilgrim frequencies became too high. In Woerleschwang in the district of Augsburg, where the Albertus reliquary and the figure of the Virgin Mary developed into a less well-known national pilgrimage that only gained some momentum in the 18th century, the responsible local pastor Matthias Winterholler reported as early as 1713: "Only a few days a year pass before a pilgrim comes". And in 1760 one of his successors added: "Throughout the whole year pilgrims come almost daily to Our Lady and St. Albertus". Dizzying numbers of read masses, confessions, and administered communions are taken from the traditional registers of pilgrimages, such as the pilgrimage Maria Hilf on the Lechfeld. [31] At the beginning of the 18th century, the number of mass visitors who went to confession and communion reached the annual mark of 40,000. In 1714/15 Maria Hilf exceeded the number of 50,000 and already in $1719 / 20$ a record number of 105,000 communions was reached. 
This also gave cause for thought in church circles. [32]

In the spiritual territories and the imperial church a discourse developed about the high number of Catholic sacrifices, consecrations and holidays, which in the eyes of economically oriented educational circles could only lead to idleness and refusal to work. Also in the Franconian high monasteries one took position on it. In Wuerzburg in 1770, for example, a concrete response was made by decree. The legislator took up the discourse about idleness: "Die leidige Erfahrniß zeiget aber, daß die Feyrung allzu vieler Ta ${ }^{e}$ ge dem geistlichen und zeitlichen Wesen mehr schadlich, als vortra glich, und dem vorberuehrten Endzweck selbst hinderlich geworden ist. Der eingerissene Weltgeist verkehret solchen, und begnu ${ }^{e}$ get sich statt Heiligung des Tags eine halbe Stund Gott zu schenken, hingegen die ganze ihrer Bestimmung nach heiligen Tage veranlasset selber bey dem meisten Theil des Volkes durch alle Gattungen der Ausgelassenheit und Verschwendung zu begehen. Folgen des angewo ${ }^{e}$ hnten $M u^{e} \beta i g g a n g s$, welcher die verderblichen Wirkungen auf die Sitten der Menschen, und auf ihr ewiges und zeitliches Wohl ausgießet, denen auch die gescha reftesten Gesa tze nicht vorbeugen und abhelfen ko nnen." [33] The sovereign Adam Friedrich von Seinsheim (1755-1779) had a list of feasts of saints drawn up, the worship of which had to be postponed until the following Sunday. It was attached to the corresponding Policey order. "Verzeichnuß der Heiligen, deren Geda chtnuß und Verehrung in der a ußerlichen Feyer auf den na $a^{e}$ chst vorhergehenden Sonnta gen begangen werden soll: H. Mathias. H H. Philipp und Jacob. Maria ${ }^{e}$ Heimsuchung. H. Maria Magdalena. H. Jacobus. $H$. Laurentius. H. Bartholoma us. H. Mattha us. H. Michael. H H. Simon und Judas. H. Martinus. Maria Opferung. H. Andreas. H. Thomas. H. Johannes Evangelist. Der dritte Oster- und Pfingsttag, dann unschuldigen Kindleins-Tag an jenen Orten, wo er bishero gefeyert worden, werden ga nzlich aufgehoben." [33]

\section{Polemics of Enlightenment}

In the Enlightenment, church-critical authors and writers increasingly bundled objections raised since the Reformation against piety cults, indulgences, worship of saints, belief in miracles and the pilgrimage system as a whole. Pilgrimages were based on an endlessly proliferating cult of saints and relics which, thanks to endless "fables and embellishments" around the mostly "tiny spark of possible sincerity" and curious canonizations after the Reformation, reached a new peak in the late 17 th and early 18 th centuries. At the same time a lucrative devotional trade flourished which led to the multiplication of mummified saints. There were at least 26 places of pilgrimage to the bones of St. George and the skulls of the Three Kings were venerated simultaneously in Cologne and Milan. Blood miracles as in the well-known Wallduerner pilgrimage [34] - there the picture of the Holy Blood arose from spilled wine in the chalice cloth - were deconstructed as superstitions. The cult of relics was linked to pre-Reformation forms of piety, which alone, for example, brought over 5000 individual relics to the castle church in Wittenberg. [35] However, not all pilgrimage and pilgrimage sites suffered a decline in piety towards the end of the 18th century. The devotion that began soon after the death of the Franciscan Maria Crescentia H ö $\beta$ (1682-1744) brought incessant streams of pilgrims to the otherwise predominantly Protestant imperial city of Kaufbeuren. (Figures 1 and 2, Maria Crescentia Höß). The chroniclers counted up to 70,000 people annually at the grave of the Franciscan nun. The Roman Curia therefore initiated the process of beatification in 1775 as a result of miraculous prayer responses and ceaseless worship against the flow of time. However, the canonization did not take place until November 2001.

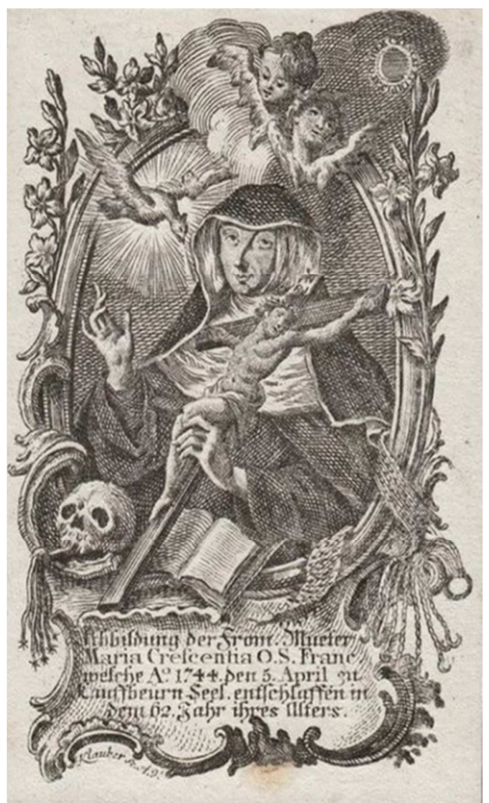

Figure 1. St. Crescentia Höß. Copperplate from the workshop of Johann Baptist Klauber from Augsburg, around 1790. Image template: archive of the author.

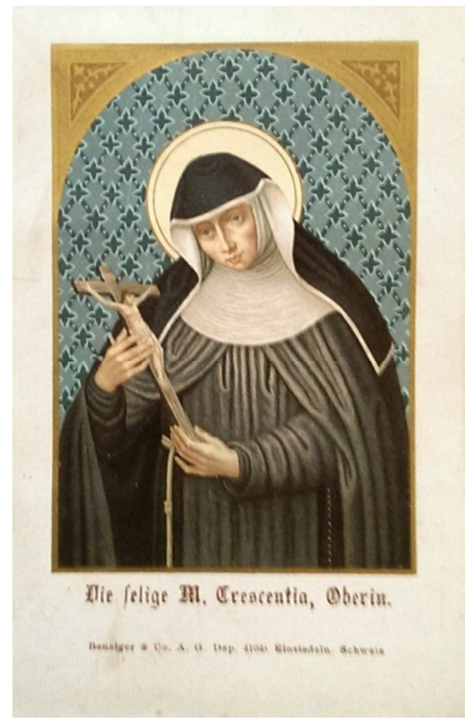

Figure 2. Prayer slip from the Swiss pilgrimage in Einsiedeln, $20^{\text {th }}$ century. Image template: archive of the author. 
The criticism of the late 18 th century tied in with arguments of the Reformation period, in which pilgrimages were described as "childish, unnecessary works" - as in the Confessio Augustana. [36] There were curiosities about the veneration of saints to be reported in chronicles and printed matter. In 1562 the Gandersheim chronicle reported as a deterrent example about a rat which was worshipped and adored by Christians in Lyon. At first Martin Luther was still cautious in his programmatic writing "An den christlichen Adel deutscher Nation" aus: "Das sag ich nit darum, daß Wallfahrten böse seien, sondern daß sie zu dieser Zeit übel greaten". Und in der "Jakobus-Predigt" legte er mit Blick auf Santiago de Compostela [37] deutlicher nach: "Hat aber jemand ein Gelübde getan, zu Sankt Jacob zu reisen oder an andere Orte, der laß es hinfahren. Es ist ein Gelübde wider deine Seligkeit, denn Gott hat kein Gefallen an den Narrenwerken noch an solchen Gelübden. Doch sollst du solch dein närrisch und ungöttlich Gelübde bereuen und Gott um Gnade bitten, daß er dir solche Unwissenheit und Unglauben wolle verzeihen". [38] The Swiss reformers were even more critical. Ulrich Zwingli found the "foolish" pilgrimage reprehensible as an act of grace in his "closing speeches": "Zum 3. hört man ouch an den worten Christi unnd der tat Davids, Mat. 12. [Matth. 12. 3f.] anzeigt, daß die närrisch handlend, so die gnad gottes an besundere stett bindend, als gen Rom, gen Hierusalem, gen sant Jacob unnd an andre vil ort, ja nit allein närrisch, sunder ouch antichristenlich; denn sy machend die gnad gottes an einem ort bereiter und wolfeiler dann am andren, welchs nüt anderst ist weder got inschliessen und anbinden, das ist: die gnad gottes fahen und nit lassen bekant werden, als sy aber billich solt. Namlich also: das, an welchen orten uff erdrich er angeruefft würdt, da ist er und spricht: Ich bin hie." [39] And for the Geneva theologian John Calvin, who took part in his mother's pilgrimages to Picardy during his childhood, pilgrimages were "filled with manifest godlessness." [40] On the whole, the Reformation's criticism of pilgrimage practice led to a dramatic collapse of pilgrimages in Protestant territories. [41] While in the 16th century theological and biblical arguments were increasingly used, the increasingly sharp criticism of pilgrimages became secular until the Enlightenment.

The philanthropist and writer, Dr. med. Jonas Ludwig von Heß (1756-1823), wondered about the superstition in town and country on his journey through southern Germany around 1795. Heß, who was born in Stralsund, worked as an editor in Hamburg and received his doctorate in 1801 in Königsberg with a thesis on medical history, made a note on pilgrimages in the backyard of the bishop's residence in Dillingen along the Danube: "Es war an einem Feiertage, als ich durch diese Gegend kam, und die Landstraße war mit Wallfahrern gefüllt, die von Mutter Annen zurückkamen. Die mehrsten Haufen bestanden aus 20 bis 30 Personen. Der Vorderste las das Evangelium, und so wie er eine Periode ausgesprochen hatte, schrie alles: 'Heilige Mutter Gottes Maria, bitte für uns Sünder.' Dabei ließ jeder einen Knopf seines Rosenkranzes fallen. Diese Aufzüge machten einen ängstlichen, schwermütigen Eindruck. Die Menschen gingen alle niedergedrückt, gepreßt und wie von schweren Gewissen belastet, einher. Sie glichen den unglücklichen Ketzern, die von der heiligen Inquisition zum Scheiterhaufen geschleppt wurden." [42] Heß did not mention the singing of pilgrimage songs, the texts of which have already been handed down in 15 th century manuscripts. They had the function of giving new confidence to pilgrims who were plagued by uncertainty and timidity in the face of their strains. We are familiar with some of these songs from the Bavarian monastery of Wessobrunn. Whether they had a spiritual brightening effect may be left open by the example of the veneration of Peter: "Sanctus Petrus der ist güt der uns vil seiner genaden tüt das gepewt im die Gotes styme fröleichen fara wur nu hilff uns edle Maria zew dir [...]. "The second verse was then: "Sanctus Petrus won uns pey wenn wir schullen sterben Mach uns aller sünden frey und laß uns nicht verderben. Vor dem thofel uns bewar reyne mayt Maria und für uns an der angel schar so singa wir Alleluia..." [43]

It was therefore no coincidence that a connoisseur of the bischop's state, the Ellwanger Hofrat and grandson of the Dillinger chancellor and feudal provost, Joseph von Sartori [44], who died in 1732, expressed his opinion on the pilgrimage system. His constitution-oriented work ("Staatistische Abhandlung über die Mängel in der Regierungsungsverfassung [...], 1787") was written as a price pamphlet for the 25 ducats offered in the "Journal von und für Deutschland" by the Fulda Cathedral Chapter and President of the Government Philipp Anton von Bibra [45] in 1786. The following questions had to be answered: " $D a$ die Staaten der geistlichen Reichsfürsten Wahlstaaten und überdies größtentheils die gesegnetesten Provinzen von ganz Deutschland sind, so sollten sie von Rechtswegen auch die weisesten und glücklichsten Regierungen genießen. Sind sie nun nicht so glücklich, als sie seyn sollten, so liegt die Schuld nicht sowohl an den Regenten, als an der inneren Grundverfassung. Welches sind also die eigentliche Mängel? und wie sind solche zu heben?" [46] Sartori, like other time critics, recognized useless pastimes in religious customs, whereby the economically lucrative pilgrimage system [47] was also declared to be a matter harmful to the state. If "die Industrie in einem geistlichen Lande Fortschritte machen soll, so müssen auch alle den Fleiß der Unterthanen störende Gelegenheiten auf die Seite geräumt werden. Hieher gehören allerdings und vorzüglich die Wallfahrten. Z. B. Loretto zählt alle Jahr 5000 teutsche Pilgrime, unter diesen ist gewi $\beta$ die Hälfte aus den geistlichen Stiftsstaaten. Man berechnet nicht, wie vieles Geld diese Leute an Opfer und Zehrungen aus dem Land tragen, weil sich in jedem Stiftsstaat auch eine oder mehrere Wallfahrten befinden, die reichlichen Geldzuflu $\beta$ von den Ausländern erhalten: Nur die Versaumni $\beta$ und die vielen Arbeitshände, die solche weite Wallfahrtsgänge dem Staat rauben, machen einen beträchtlichen Verlust." [48]

Although the pilgrim streams to the Madonna of Grace, which Sartori named as the second most important place of pilgrimage in Italy, appear high and regionally not differentiated, the popularity of the Loreto Churches and the 
Holy House of Nazareth, which were often reconstructed to scale in southern Germany, speaks for an unbroken pilgrimage boom which lasted until Napoleonic times. For the pilgrimage north of Augsburg to the Loreto Chapel and its Black Madonna "auf dem Kobel", a source-oriented study is available as a contribution to European cult and cultural history that provides information about the catchment area and the extent of regional pilgrim flows. [49] Martina Haggenmüller also quantified concrete lists of pilgrims in her dissertation on the pilgrimage to Rome. According to the pilgrims' hospice of Santa Maria dell'Anima [50] in Rome, 872 pilgrims from the diocese of Augsburg were registered there for four decades between 1778 and 1819. The share of this diocese in the registration list of 8698 pilgrims to Rome was thus one tenth. [51] These were - mind you - the calculations from only one of the central hospices in Rome, which however had high attraction for the German-speaking countries. But even there, after the occupation of Rome in 1798 , the church was sys-tematically plundered by French troops. Sartori's concerns about losses of foreign exchange at home as a result of popular long-distance pilgrimages may not be historically appropriate from the point of view of piety, but economically they apply. Individual references such as that to 60-year-old Wolfgang Geiselmayer from Dinkelscherben complete the picture. The innkeeper from the official residence of the Augsburg Cathedral Chapter asked for a viaticum in 1650 because he intended it, "zue gewinnung gegenwärtigen Jubiläi negster tegen nacher Rom $z u$ raisen". [52] The criticism of the money-wasting pilgrimage practice and the veneration of Rome, like other arguments of the Enlightenment, could already be read in Luther's "To the Christian Nobility of the German Nation": "Abgethan werden sollen die Fastengebote, weil diese Menschensatzungen der evangelischen Freiheit entgegen seien; abgeschafft die vielen Feste und Feiertage, weil sie Müssiggang, Saufen und Spielen mit sich bringen; gesteuert dem fürwitzigen Wallfahren nach Rom, bei dem man schweres Geld verzehre, während man Weib und Kind und die armen Mitchristen daheim darben lasse, und bei dem man in Aergerniß und Versuchung hineinlaufe." [53]

Criticism of the pilgrimage system also came from other sides. It was then the Neresheimer Hofrat and Erbkaplan Jacob Friedrich Döhler, who brought the Catholic "doing nothing" into series of figures that could be analysed from an economic and business point of view. In doing so, he referred to denominational comparisons as their immediacy could only be achieved in the two-denominational imperial cities of southern Germany. [54] Specifically, he put the work performance in these cities in relation to each other:... in der catholischen Manufaktur oder Fabricke dörfen keine protestantische, und in dieser keine catholische Arbeiter angestellt werden, und beide müßen des bekanten Simultanei in der Anzahl der Arbeiter einander stets gleich seyn: In Ansehung der Güte, und des Verschleisses der Waaren hätten sie gleiche Rechte und Freiheiten nach der Wahl der Käufer zu geniesen. Die protestantische Manufaktur oder Fabrick arbeitet in einem Jahre 309 Täge mit 30 Arbeitern, die catholische aber [auch als Folge des ständigen Wallfahren] nur 284 Täge mit 30 Arbeitern: Man gebe einem jeden Arbeiter per aversum täglich $30 \mathrm{kr}$. lohn; so verdienen die protestantische Arbeiter in 309 tagen a 154 flor. $30 \mathrm{kr}$. zusammen $4635 \mathrm{fl}$. die catholische 30 Arbeiter aber verdienen in 284 Tägen nur 4260 flor. und werden mithin die protestantische Arbeiter alle Jahr um 375 flor. reicher, als die 30 catholische Arbeiter.... " [55] And a different judgment of the Enlightenment period on the monastery pilgrimages was particularly blatant when Ernst von Klenk, as court councillor, equated religious asceticism and monastic ideals with state and economic ruin: "Ein erlicher Mann solte sich schaemen ein Moench zu sein und auf kosten andrer Arbeitsamer im Nichtstun seinen Bauch zu fuellen." [56]

The criticism of pilgrimages remained linked to general reservations against the Catholic educational and territorial world in the Germania Sacra. Enlighteners made an arch around the high monasteries, monasteries and monasteries with their important pilgrimage churches. According to such estimates only citizens lived in Bamberg who "prefer peace to all else, and these do not exist, but find that under the crook one can not only live well, but digest quite comfortably". [57] For the cathedral city of Freising similar warrantors of livable bliss were quickly named: "an unfading beer mug, undisturbed idleness" and above all many silent devotions. [58] In the university town of Dillingen, one could still study philosophy in 1802, but "no philosopher is allowed to show his face. The word is an abomination", instead there prevails a calmness far removed from criticism and education. [59] It was not worth going to the baroque residence city of Eichstätt of the Franconian prince-bishopric of the same name, because the city "was such a miserable nest, thrown in a corner of mountains that [even] the nature of it was ashamed of itself, and therefore covered such with an eternal fog". [60] The fog and storm metaphor widespread in the literature of the 18th and 19th centuries as a symbol of superstition, lack of enlightenment, crime [61], unorthodox and negligent criminal justice [62], disorderly state relations and chaotic government systems - in short "bad governance" - was also encountered elsewhere. Occasionally incense ensured that sacralized wafts of fog did not atomize even in sunshine.

On pilgrimages in 1788 the Jena court councillor Andreas Josef Schnaubert responded to Friedrich Carl Freiherr von Moser's hypothesis that spiritual countries were backward. "Der Frhr. v. Moser schlägt dieselbe in den deutschen geistlichen Staaten ausdrücklich blos zum Vortheil der Protestanten vor, um Industrie, Bevölkerung und Reichthum darinn zu vermehren. Die Erfahrung lehrt, daß die Protestanten im Durchschnitte vielthätiger, arbeitsamer, nachdenkender, unternehmender, abgehärteter, attenter auf ihre Sachen, und sparsamer sind, als die Katholicken. Bei jenen haben Ackerbau, Handlung, Fabriken, Künste und Wissenschaften von jeher viel mehr, als bei diesen, geblühet. Die häufigen Wallfahrthen, Fast-Feyertage, Kirchengänge, auch auf Werktagen, privat Andachten, die einigemal in der Woche abgewartet seyn wollen, das lesen der, wegen der vielen Wunderthaten, und sonderbaren Begebenheiten sehr 
reitzenden Legenden der heiligen, die unächte Moral von der niemand verlassenden Vorsehung, vom häufigen und indiskreten Allmosengeben, besonders an geistliche und Mönche, die Christum dabei vorstellen sollen, deren gestalt derselbe angenommen haben könne, und die Furcht, allenfalls ihn sogar von der Thüre wegzuweisen, welches leicht mit der Verweisung von der Thür des Himmels einst werden könnte, die unrecht verstandene, oder wenigstens dem gemeinen Haufen unrichtig vorgetragene Lehre vom beständigen Gebet, von der Verachtung alles zeitlichen, und der einzig nöthigen Sorge für die zukünftige Seeligkeit, und der auf manche vermeintliche Andachts- und Tugendübungen nothwendig folgende stärkere Appetit zum Essen, Trinken und Müssiggang, der Hang, sich für das ausgestandene wieder etwas gutes zu thun $u$. dergl., sind wohl die leicht zu denkenden Ursachen, daß der katholische gemeine Mann indolenter, schlaffer, müssiger, verschwenderischer und ärmer ist als der protestantische." [63]

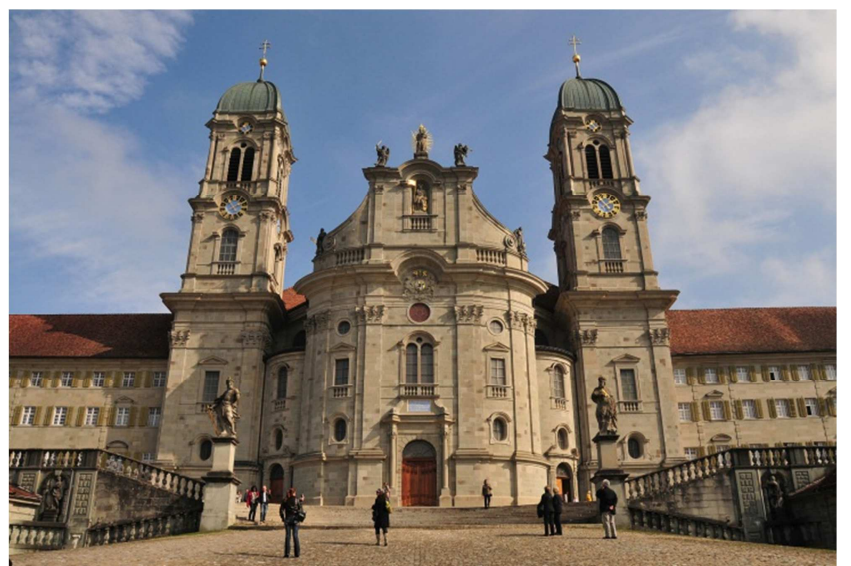

Figure 3. Monastery and pilgrimage church in Einsiedeln, 2008. Image template: Wikipedia, public domain.

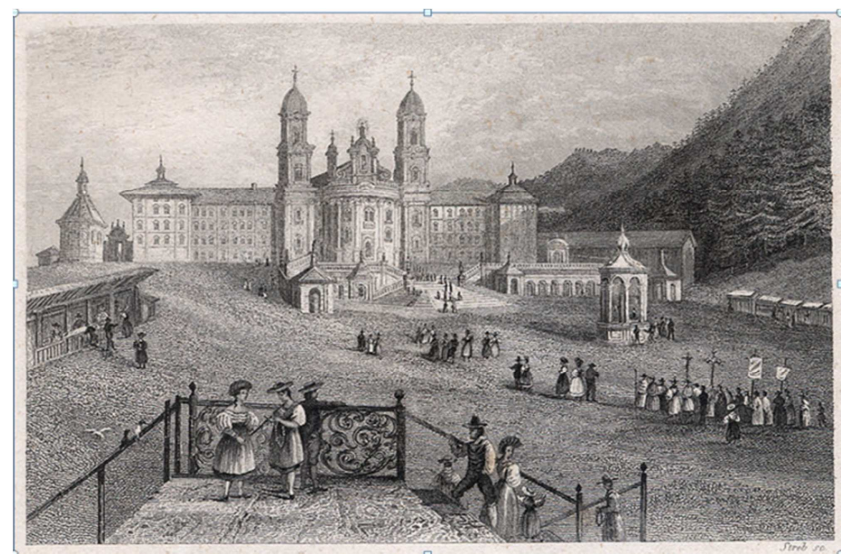

Figure 4. Einsiedeln monastery, middle of the $19^{\text {th }}$ century. Image template: archive of the author.

A Benedictine priest from the abbey and the pilgrimage centre of Maria Einsiedeln (Figures 3, 4 and 5) - the Black Madonna in the Chapel of Grace is still the centre of attraction for countless pilgrims - took up criticisms from Protestant enlighteners as the monastery economist concerned, animated by the spirit of Catholic enlightenment and Josephine church reforms. In 1788 he published under the pseudonym Auriophilus Fischer in his 98-page book "Bilderdienst, Wallfahrten und Wunder" serious doubts about outdated baroque forms of faith, picture worship, superstition, senseless piety and miraculous pilgrimage. The author explained: "Warum heißt es denn Gnadenbild, wunderthätiges Bild, Mirakelbild? Kann es einen gro ßeren Irrthum geben, als das Wort Gnadenbild in der Bedeutung, wie manns nimmt, und die Bilderverehrer es zu nehmen lehren? Was muß wohl die Wallfahrt mehr befo rdern, als eben das Vertrauen, das man albernen, abergla ubischen Herzen vorzugsweise gegen ein Bild vor jedem andern einzuflo ${ }^{e}$ ssen sucht? Wenn der Christ mit Ueberlegung glaubte, daß kein Bild in der Welt mehr vermo ${ }^{e}$ ge, mehr vermo ${ }^{e}$ gen $d u^{e} r f e$, als uns auf den Gegenstand, den es vorstellt, zu erinnern, warum genu gt es uns nicht an unsern Bildern in unserm Betbuche, in unserm Zimmer? warum suchen wir dieses Bild zu Maria Taferl, zu Zell auf? [...] Heißt das nicht Leute in Irrthu mer und Aberglauben stu rzen?" [64]

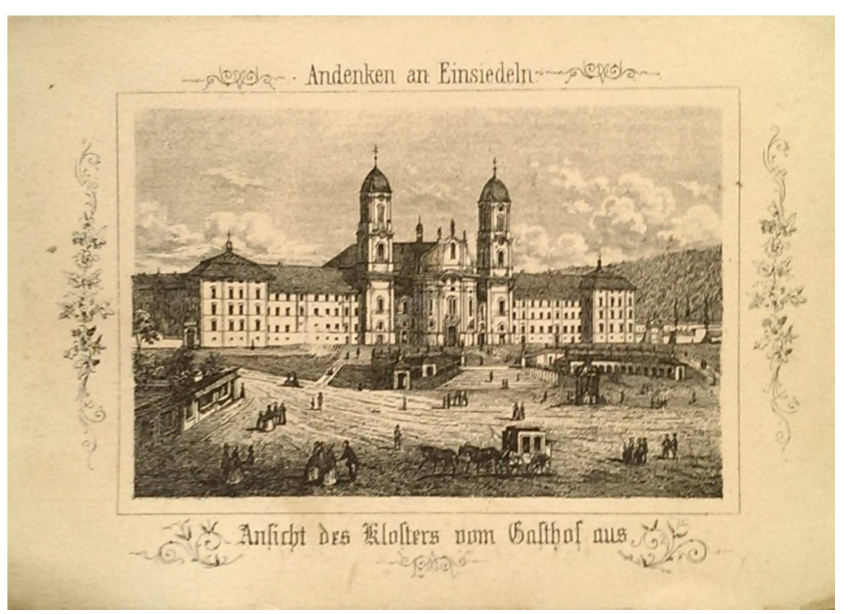

Figure 5. Close-up view of the monastery from the brewery, $20^{\text {th }}$ century. Image template: archive of the author.

\section{Conclusions}

Contrary to the mainstream of previous pilgrimage research, which focused on the early and emerging period of pastoral piety and the increasingly popular worship of healing images of grace, this contribution dealt with the late period of the South German pilgrimage system. Sharp criticism of the cult practice of small and large pilgrimage centres, discredited as idolatry, began in the Reformation. Now there were suddenly curiosities about medieval veneration of Saints to be reported in chronicles and printed matter. In 1562, for example, the Gandersheimer chronicle reported as a deterrent example about a rat that was worshipped for a very long time by believers in the French town of Lyon. These and other forms of pilgrimage polemics were widespread via printed matter, but they did not in any way lead to an interruption of the pilgrim flows. On the contrary, pilgrimage centres flourished not only in the Germania Sacra through the serving of popular 
monastic beers, good gastronomy and the flourishing trade in devotional objects and relics. Pilgrimage churches also attracted crowds of beggars who could hope for the pilgrims' charity. The Enlightenment finally continued the older Reformation objections to piety and indulgences in its kind of fundamental criticism. The early modern Policeysystem now concentrated above all on the great streams of pilgrims in the direction of Rome or Santiago di Compostela. For the economic development of the regions of origin of the pilgrims they were supposedly disastrous, as they paid foreign exchange and animated the affected people to pray "uselessly" far away from home instead of working.

\section{References}

[1] Preliminary remark: German book titles and contemporary quotations have been translated only occasionally. See for the well-researched and known pilgrims' location Altötting in Bavaria: R. Bauer, Die bayerische Wallfahrt Altötting, Munich 1970; O. Wiebel-Fanderl, Die Wallfahrt Altötting: Kultformen und Wallfahrtsleben im 19. Jahrhundert [New Publications of the Institute for East Bavarian Homeland Research of the University of Passau 41) Passau 1982; F. X. Hoedl, Altötting. History of a place of pilgrimage, Altötting 1984; G. P. Woeckel, Pietas Bavarica: Pilgrimage, Procession and Ex-voto-gift in the House of Wittelsbach in Ettal, Wessobrunn, Altötting and the State Capital Munich from the Counter-Reformation to Secularization and the "Renovatio Ecclesiae", Weißenhorn 1992; P. Moser, Altötting: Mythos, Geschichte, Wahrheit, München 2004; J. Zellner/ C. Meinecke, Altötting: Germany's most famous Mary's pilgrimage site depicted on the basis of the spatial images in the diorama show Altötting, the Mary's documentations from 1950 and 1977 as well as historical and current images, Altötting 2009.

[2] K. Herbers, "Wol auf sant Jacobs straßen". Pilgrimages and testimonies of the James cult in southern Germany, Ostfildern 2011.

[3] E. Lobenwein, Pilgrimage - Miracle - Economy. The pilgrimage to Maria Luggau (Carinthia) in the early modern period, Bochum 2013.

[4] The Weltbild publishing house offers such an annual calendar. For 2013 it comprised 14 colour illustrations. The dimensions were $59.4 \times 42 \mathrm{~cm}$.

[5] H.-J. Wolf, Sins of the Church. The Business with Faith: Heresy - Crusades - Jewish and Women's Hate - Saints and Relic Cults - Celibacy - Morals, Hamburg 1998.

[6] State archives Augsburg, Hochstift Augsburg, K [asten] Nr. 19 (old signature: Bayerische Staatsverwaltung Nr. 2827), Memorial from the pulpit by the cathedral preacher Georg Zeiler of Augsburg against the order to approve the cloisters' cessations to "Holy Mountain" in Andechs, 11. 5. 1787.

[7] Krüger, South French local saint between church, dynasty and city from the 5 th to the 16 th century (Contributions to hagiography 2) Stuttgart 2002.

[8] Quoted after: N. Ohler, pilgrim staff and scallop. Pilgrimages in middle ages and modern times, second edition, Düsseldorf
2003, p. 61 .

[9] W. Wüst, Prince-bishop's office and government in the Hochstift Augsburg under Clemens Wenzeslaus of Saxony, 1768 1803, in: P. Fried (ed.), Miscellanea Suevica Augustana. Presented to the city of Augsburg for the 2000th anniversary 1985 (Augsburger Beiträge zur Landesgeschichte Bayerisch Schwaben 3) Sigmaringen 1985, pp. 129-147.

[10] D. Drascek, How the miracle healer and exorcist Johann Joseph Gaßner (1727-1779) cast out the devil and thereby heated the minds of his contemporaries. From the advance of the enlightenment and the wavering faith in the power of evil, in: K. Unger/ K. Geiger/ S. Tausch (ed.), Brücke zum Wunderbaren (Bridge to the Wonderful). Of pilgrimages and religious images. Expressions of piety in Eastern Swabia. Volume accompanying the exhibition at the Historisches Museum in Regensburg 15. April to 6. July 2014, Regensburg 2014, pp. 273-279.

[11] W. Wüst (ed.), Die "gute" Policey im Reichskreis. Zur frühmodernen Normensetzung in den Kernregionen des Alten Reiches, vol. 6: Policeyordnungen in den fränkischen Hochstiften Bamberg, Eichstätt und Würzburg. Ein Quellenwerk, Erlangen 2013, p. 468.

[12] K. Pörnbacher, Crescentia Höß begegnen, Augsburg 2001; DERS., Die heilige Crescentia Höß von Kaufbeuren, Lindenberg i. Allgäu 2002.

[13] H. Dussler (ed.), Reisen und Reisende in Bayerisch-Schwaben und seinen Randgebieten in Oberbayern, Franken, Württemberg, Vorarlberg und Tirol (Veröffentlichungen der Schwäbischen Forschungsgemeinschaft 6/1-2), 2 vol., here: vol. 2: Weißenhorn 1974, p. 223.

[14] Quoted after: K. H. Bachmann/ W. Specht, Glaube, Wunder, Kunst und Geöd. 700 Jahre Wallfahrt nach Hessenthal, Mespelbrunn 1993, p. 37.

[15] L. Braun, Votivbilder aus Bamberg, Burgwindheim, Glosberg und Vierzehnheiligen in den Sammlungen des Historischen Vereins Bamberg, in: Bericht des Historischen Vereins Bamberg für die Pflege der Geschichte des Ehemaligen Fürstbistums 133 (1997) pp. 357-376.

[16] It was the pilgrimage church of Maria Steinbach. Cf. in addition: Maria Steinbach. 250 Jahre Wallfahrt zur Schmerzhaften Muttergottes 1734-1984, Weißenhorn 1984.

[17] W. Pötzl, Ein dichtes Netz von Wallfahrtsorten und Gnadenstätten, in: W. Pötzl (ed.), Kirchengeschichte und Volksfrömmigkeit (Der Landkreis Augsburg 5), Augsburg 1994, pp. 157-192, hier: S. 181.

[18] K. J. Bade, Altes Handwerk, Wanderzwang und Gute Policey: Gesellenwanderung zwischen Zunftökonomie und Gewerbereform, in: VSWG 69, 1982, S. 1-37; G. Schuck, Überlegungen zum Verhältnis von Arbeit und Policey in der Frühen Neuzeit, in: Ius Commune 22 (1995) pp. 121150 .

[19] Möller, Die Gesundheit im Dienste der Staatsraison. Zur Theorie der Medizinalpolizei im 18. und 19. Jahrhundert, in: L. Pahlow (ed.), Die zeitliche Dimension des Rechts: Historische Rechtsforschung und geschichtliche Rechtswissenschaft, Paderborn 2005, pp. 201-221; C. Möller, Medizinalpolizei. Die Theorie des staatlichen Gesundheitswesens im 18. und 19. Jahrhundert (Studien zu Policey und Policeywissenschaft) Frankfurt/ Main 2005. 
[20] W. Th. Rauen, Gedanken von dem Nutzen und der Nothwendigkeit einer medicinischen Policeyordnung in einem Staat, Regensburg ca. 1760; M. Dinges, Medicinische Policey zwischen Heilkundigen und "Patienten" (1750-1830), in: K. Härter (ed.), Policey und frühneuzeitliche Gesellschaft, Frankfurt a. Main 2000, pp. 263-295.

[21] To the general introduction cf. Th. T. Müller, Wallfahrt und Bier. Untersuchungen zu einem bedeutenden Wirtschaftsfaktor bei spätmittelalterlichen Wallfahrten, in: D. Doležal / H. Kühne (ed.), Wallfahrten in der europäischen Kultur = Pilgrimage in European culture. Tagungsband Př́ibram, 26. 29. Mai 2004 (Europäische Wallfahrtsstudien 1) Frankfurt/M. [a. o] 2006, pp. 317-331.

[22] The beer is named after the pilgrimage church in the northeastern part of the town of Pfarrkirchen.

[23] County of Bayreuth.

[24] URL: http://www.ratebeer.com/beer/gossweinsteinerwallfahrtsbier/134373/[access: 30. 3. 2019]

[25] State archives Augsburg, Hochstift Augsburg, NA, Akten, Nr. 2242, letter dated from 21. 1. 1788.

[26] H. Dussler (ed.), Reisen und Reisende in Bayerisch-Schwaben und seinen Randgebieten in Oberbayern, Franken, Württemberg, Vorarlberg und Tirol, vol. 2 (see note 14) p. 290.

[27] B. A. Tlusty, Bacchus und die bürgerliche Ordnung. Die Kultur des Trinkens im frühneuzeitlichen Augsburg (Studien zur Geschichte des Bayerischen Schwaben 34) Augsburg 2005.

[28] In Bamberg ruled Adam Friedrich von Seinsheim since the year 1757.

[29] W. Wüst (ed.), Die "gute" Policey im Reichskreis. Zur frühmodernen Normensetzung in den Kernregionen des Alten Reiches, vol. 6 (see note 12), p. 171.

[30] W. Wüst (Hg.), Die "gute" Policey im Reichskreis. Zur frühmodernen Normensetzung in den Kernregionen des Alten Reiches, vol. 6 (see note 12), p. 105.

[31] A. Kohlberger, Maria Hilf auf dem Lechfeld: 400 Jahre Wallfahrt (Beiträge zur Heimatkunde des Landkreises Augsburg 18) Augsburg 2003.

[32] Quoted after: W. Pötzl, Ein dichtes Netz von Wallfahrtsorten und Gnadenstätten, in: W. Pötzl (ed.), Kirchengeschichte und Volksfrömmigkeit (Der Landkreis Augsburg 5) Augsburg 1994, pp. 171, 187.

[33] W. WÜst (ed.), Die "gute" Policey im Reichskreis. Zur frühmodernen Normensetzung in den Kernregionen des Alten Reiches, vol. 6 (see note 12) p. 164.

[34] W. Bruckner, Die Verehrung des Heiligen Blutes in Walldürn, Dissertation Frankfurt am Main 1956, Aschaffenburg 1958.

[35] H.-J. Wolf, Sünden der Kirche (see note 5) pp. 635-666, here: pp. $642,644,659$.

[36] S. Bräuer, Wallfahrt in reformationsgeschichtlicher Perspektive. Forschungsgeschichte und Desiderata, in: J. Hrdina/ H. Kühne/ Th. T. Müller (ed.), Wallfahrt und Reformation - Pout' ${ }^{`}$ a reformace. Zur Veränderung religiöser Praxis in Deutschland und Böhmen in den Umbrüchen der Frühen Neuzeit (Europäische Wirtschaftsstudien 3) Frankfurt/Main 2007, pp. 29-62, here: p. 29.
[37] C. Kühn, Die Pilgerfahrt nach Santiago de Compostela. Geschichte, Kunst und Spiritualität (Peregrinationes Schriften zur Pilger- und Sakrallandschaft Mitteldeutschlands 1) Leipzig 2005.

[38] D. Martin Luthers Werke. Kritische Gesamtausgabe (Weimarer Ausgabe), Abtl. Schriften, vol. 6 (Schriften 1519/20) p. 437 und vol. 17/ II (Fastenpostille), p. 465.

[39] Huldreich Zwinglis sämtliche Werke, vol. 2 (Corpus Reformatorum 89) Leipzig 1908, "Auslegen und Gründe der Schlußreden” from 14. July 1523, p. 248.

[40] E. Busch (ed.), Calvin-Studienausgabe, vol. IV (Reformatorische Klärungen) Neukirchen-Vluyn 2002, No. 13,7 .

[41] H. Kühne, Zwischen Bankrott und Zerstörung - vom Ende der Wallfahrten in protestantischen Territorien, in: J. Hrdina/ H. Kühne/ Th. T. Müller (ed.), Wallfahrt und Reformation (see note 38) pp. 201-220.

[42] H. Dussler (ed.), Reisen und Reisende in Bayerisch-Schwaben und seinen Randgebieten in Oberbayern, Franken, Württemberg, Vorarlberg und Tirol, vol. 2 (see note 14) pp. $318 \mathrm{f}$.

[43] Quoted after: M. Haggenmüller, Als Pilger nach Rom. Studien zur Romwallfahrt aus der Diözese Augsburg von den Anfängen bis 1900 (Materialien zur Geschichte des Bayerischen Schwaben 18) Augsburg 1993, p. 193; Bavarian State Library Munich, Handschriften, Cgm 444, fol. 13.

[44] Joseph Georg von Sartori held the following offices and positions: Imperial knight, k. k. Imperial Hofrat (since 1788), stift-kemptischer and hochstift-augsburgischer privy councillor, hochstiftischer chancellor and feudal provost. Cf A. Kraus, Wissenschaftliches Leben 1550-1800, in: Handbuch der bayerischen Geschichte III/ 2, ed. by Max Spindler, München 1971, pp. 1138-1163, here: p. 1140.

[45] P. A. v. Bibra, who was born in Bamberg in 1750, received a canonicat at the Fulda Cathedral Chapter in 1778, was promoted to president of the Court Chamber there in 1782 and, under prince-bishop Heinrich v. Bibra, was appointed president of the financial chamber in 1786. Cf. W. v. Bibra, Beiträge zur Familiengeschichte der Reichsfreiherren von Bibra, München 1880; W. v. Bibra, Zur Biographie des Heinrich Freiherrn von Bibra, Fürstbischofs von Fulda, died 25. th of. September 1788, München 1887.

[46] Quoted after: P. Wende, Die geistlichen Staaten und ihre Auflösung im Urteil der zeitgenössischen Publizistik (Historische Studien 396) Lübeck/Hamburg 1966, pp. 9 f.

[47] See for pilgrimages in Hochstift Augsburg: W. Pötzl, Wallfahrerinnen und Wallfahrer aus Zusmarshausen, in: W. Pötzl (ed.), Zusmarshausen. Markt, Pflegamt, Landgericht und Bezirksamt, Zusmarshausen 1992, pp. 203-222; Peter Rummel, Katholisches Leben in der Reichsstadt Augsburg (1650-1806), in: Jahrbuch des Vereins für Augsburger Bistumsgeschichte 18 (1984) pp. 9-161, hier: pp. 63-102. Cf. for the history of concepts: H. Dünninger, Was ist Wallfahrt? Erneute Aufforderung zur Diskussion um eine Begriffsbestimmung, in: Zeitschrift für Volkskunde 59 (1963) pp. 221-232. As a bibliographical overview last: P. Hersche, Devotion, Volksbrauch oder Massenprotest? Ein Literaturbericht aus sozialgeschichtlicher Sicht zum Thema Wallfahrt, in: Das achtzehnte Jahrhundert und Österreich, in: Jahrbuch der Österreichischen Gesellschaft zur Erforschung des achtzehnten Jahrhunderts 9 (1994) pp. 7-34. 
[48] Joseph Edler von Sartori, Staatistische Abhandlung über die Mängel in der Regierungsverfassung der geistlichen Wahlstaaten und von den Mitteln solchen abzuhelfen, Augsburg 1787, p. 194.

[49] W. Pötzl, Loreto: Madonna und Heiliges Haus. Die Wallfahrt auf dem Kobel. Ein Beitrag zur europäischen Kult- und Kulturgeschichte (Beiträge zur Heimatkunde des Landkreises Augsburg 15) Augsburg 2000; W. Pötzl, Der Aufschwung des Wallfahrtswesens. Neue Kulte, in: W. Pötzl (ed.), Kirchengeschichte und Volksfrömmigkeit (Der Landkreis Augsburg 5) Augsburg 1994, pp. 130-143.

[50] M. Matthäus (ed.), S. Maria dell'Anima. Zur Geschichte einer "deutschen" Stiftung in Rom (Bibliothek des Deutschen Historischen Instituts in Rom 121) Berlin / New York 2010.

[51] M. Haggenmüller, Als Pilger nach Rom (see note 45) pp. 389 392.

[52] W. Pötzl, Ein dichtes Netz von Wallfahrtsorten und Gnadenstätten (see note 33) p. 184.

[53] J. Köstlin, Luthers Leben, 8. edition (first edition 1882) Leipzig 1890, 7. chapter: Luther an den christlichen Adel deutscher Nation und von der babylonischen Gefangenschaft.

[54] State of research: P. Warmbrunn, Zwei Konfessionen in einer Stadt. Das Zusammenleben von Katholiken und Protestanten in den paritätischen Reichsstädten Augsburg, Biberach, Ravensburg und Dinkelsbühl von 1548 bis 1648 (VIEG, Abtl. Abendländische Religionsgeschichte 111) Wiesbaden 1983; P. Fassl, Konfession und Politik. Zur Geschichte der Parität im 18. und 19. Jahrhundert in Augsburg, in: Jahrbuch des Vereins für Augsburger Bistumsgeschichte 22 (1988) pp. 55-74; E. François, Die unsichtbare Grenze. Protestanten und Katholiken in Augsburg 1648-1806 (Abhandlungen zur Geschichte der Stadt Augsburg 33) Sigmaringen 1991.

[55] J. F. Döhler, Auch Etwas ueber die Regierung der Geistlichen Staaten in Deutschland, Frankfurt/ Leipzig 1787, pp. 29 f.

[56] E. v. Klenk, Preisfrage: Da die Staaten der geistlichen Reichsfürsten Wahlstaaten und überdies größtentheils die gesegnetsten Provinzen von Teutschland sind, so sollten sie auch der weisesten und glücklichsten Regierung geniesen; sind sie nun nicht so glücklich als sie sein solten, so liegt die Schuld [...] an der innern Grundverfassung. Welches sind also die eigentliche Mängel; Und wie sind solche $\mathrm{zu}$ heben, Frankfurt/ Main 1787, p. 156.

[57] H. H. Hofmann, “... sollen bayerisch warden”. Die politische Erkundung des Majors von Ribaupierre durch Franken und Schwaben im Frühjahr 1802, Kallmünz 1954, p. 8.

[58] J. Pezzl, Reise durch den baierischen Kreis, Faksimileausgabe der 2. erw. Aufl., Salzburg und Leipzig 1784. Vorwort, biographisches Nachwort, Anmerkungen und Register von J. Pfennigmann, München 1973, p. 65.

[59] H. H. Hofmann, “... sollen bayerisch warden” (see note 59) pp. $42 \mathrm{f}$.

[60] W. Wüst, Ein aufgeklärter Ökonom im "verfinsterten" Hochstift. Eichstätt, Spalt und der Hopfen (Aus der Spalter Heimat. Heimatkundliche Hefte 40) Spalt 2005, p. 9.

[61] Particularly frequently used in the descriptions of the London underworld by Charles Dickens.

[62] H. Rudolph corrected what she repeatedly called the "arbitrary" criminal practice of spiritual states for the Osnabruecker Hochstift as an efficient judiciary with individually appropriate sanctions. Cf. H. Rudolph, "Eine gelinde Regierungsart". Peinliche Strafjustiz im geistlichen Territorium. Das Hochstift Osnabrück, 1716-1803 (Konflikte und Kultur - Historische Perspektiven 5) Konstanz 2000; H. Rudolph, "Löblich und wol regiert"? Strafjustiz in Kurköln in der Frühen Neuzeit, in: F. Irsigler (ed.), Zwischen Maas und Rhein, Beziehungen, Begegnungen und Konflikte in einem europäischen Kernraum von der Spätantike bis zum 19. Jahrhundert. Versuch einer Bilanz, Trier 2006, pp. 199-221.

[63] A. J. Schnaubert, Ueber des Freiherrn von Mosers Vorschläge zur Verbesserung der geistlichen Staaten in Deutschland, Jena 1788, pp. 188-200.

[64] P. A. Fischer [pseudonym], Bilderdienst, Wallfahrten und Wunder, Lissabon 1788, pp. $49 \mathrm{f}$. 